Estimation of some Biochemical Parameters in Lycopersiconlycopersicum (L.) cv. Damyanti in

Response to Acid Rain

Pratibha Tomar

\title{
Estimation of some Biochemical Parameters in Lycopersiconlycopersicum (L.) cv. Damyanti in Response to Acid Rain
}

\author{
Pratibha Tomar \\ Km. Mayawati Govt. Girls (P.G.) College, Badalpur, G.B. Nagar
}

Reference to this paper should be made as follows:

\section{Pratibha Tomar,}

Estimation of some

Biochemical Parameters in

Lycopersiconlycopersicum

(L.) cv. Damyanti in

Response to Acid Rain,

Voyager: Vol. IX,

No. 1,April 2018,

pp.34-41

voyger.anubooks.com

\begin{abstract}
In the present study investigations were done to analyze the effect of acid rain on some biochemical parameters of the tested plants i.e. Lycopersiconlycopersicum (L.) CV. Damayanti. The plants were exposed to different acid water solutions of pH 5.6, 4.5, 3.5 and 2.5. The control set of plants was treated to only distilled water ( $p H$ 5.6). The plants were given treatment of acid rain solution after only 5 days of sowing till maturity of crop, after a gap of 20 days interval. It was obvious after the study that exposure to simulated acid rain affected biochemical components of leaves in treated plants and caused them to subside to a great extent. Low $\mathrm{pH}$ of simulated acid rain proved more toxic to the green pigments of treated plants as compared to the higher $\mathrm{pH}$. It was also observed that with increasing acidity the values of carbohydrate content, anthocyanin content, was decreased, whereas the values of proline and ascorbic acid content was found to increase as a result of stress developed by increasing acidity in rain.
\end{abstract}

Keywords- Acid rain, tomato, biochemical parameters. 
The term "acid-rain" first appeared in a remarkable book authored by Robert Angus Smith "Air and Rain: Beginning of chemical climatology". In the mid 1970's the existence of highly acidic rain became widely known because it appears to be reducing biodiversity through acidification of surface waters. This ecological problem was linked to emissions of oxides of sulphur and nitrogen. Small contributions derive from hydrogen chloride, carbon dioxide and other organic acids found in the air. Analysis of more than 1500 precipitation samples, with a median $\mathrm{pH}$ of 4.0 , revealed that in $80-100 \%$ of the cases, low $\mathrm{pH}$ was attributable to sulphuric and nitric acids (Galloway et al., 1976). Likens (1975) observed that precipitation of hydrogen ion contents was $60 \%$ due to sulphuric acid, $34 \%$ due to nitric acid and $6 \%$ due to various organic acids.

Acid deposition became an issue of major concern in Asia in early 1980s, nearly one decade after widespread acid deposition was recognized in Europe and America (Bhatti, 1992). Before the establishment of national monitoring networks for acid deposition in Asia, isolated surveys of acidity level and chemical composition of rain water in some Asian countries (such as China, Japan and India) indicated the occurrence ofacid rain (Bhatti,1992).

Asia is now the Global hotspot of S and N deposition (Vet et al., 2014). Since the early 2000s, the global maximum of both $\mathrm{S}$ and $\mathrm{N}$ deposition is found in East Asia including regions like eastern China and South Korea. Other areas of high deposition in Asia include sections of Pakistan, India, Bangladesh, Myanmar, Thailand, Laos, North Korea and Japan (Vet et al., 2014). It was reported that the $\mathrm{pH}$ of rainfall in China was higher due to high buffering of precipitation acidity by emissions of basic particulate matter, including soil dust (Larssen and Carmichael, 2000), anthropogenic dust (Zhu et al., 2004: Lie et al., 2011), and $\mathrm{NH}_{3}$ (mainly from agricultural activities : Kang et al., 2016).

Acid rain increases soil acidity, thus affecting flora and fauna both, causing acidification of lakes and streams thus affecting aquatic life, crop productivity and human health. In addition it also corrodes buildings, statues, bridges, fences, monuments, etc. Anthropogenic inputs of S and $\mathrm{N}$ into terrestrial ecosystem impact soil and surface water, causing acidification and eutrophication (Bowman et al., 2002). Soil acidification, as indicated by a significant decrease in soil $\mathrm{pH}$ and increase in aluminium (Al) mobilization and increased $\mathrm{N}$ leaching (Aberet al., 2003), has been commonly reported in East Asia (Larssenet al., 2011: Asano and Uchida, 2005: Fang et al., 2011). The adverse effects of high atmospheric concentrations of $\mathrm{SO} 2$ and $\mathrm{NO} 2$ on trees and agricultural crops have long been known. Plants sensitive to these gases show necrosis of leaves or needles at exposure to $\mathrm{SO} 2$ and $\mathrm{NO} 2$ in excess of current levels or anticipated levels as well as, sulphuric acid droplets for short periods. Vegetation serves as natural sink for air pollutants by producing an enormous surface of expanded leaves for absorption and setting of gases and 
Estimation of some Biochemical Parameters in Lycopersiconlycopersicum (L.) cv. Damyanti in

Response to Acid Rain

Pratibha Tomar

particulate matter.Acid rain causes reduction

in agriculture production and their biochemical quality. Relationship between

pollutant concentration and response of plants depends upon many factors such as species condition, stage of development, sensitivity of seedling etc. The variation in the plants response to acid rain may be due to interaction of rain treatment with a number of biological, chemicaland climatic factors.

In recent years the acidity of rain and snow has increased sharply all over India. Acid rain with $\mathrm{pH} 4.8$ was reported in Greater Mumbai in 1974-75. (Negi, 1983). Low pH levels have also been reported from Delhi, Maharashtra, Uttar Pradesh, Madhya Pradesh, Tamil Nadu and even the Andaman Island. An analysis of data obtained from ten Indian Background Air Pollution Monitoring Stations (BAPMONS) collected during 197485 shows that a few areas are already under stress conditions (Khemaniet al., 1989). According to researchers at Tata Energy Research Institute (TERI), by the year 2020, the energy demands in India is expected to increase by 300 percent from the present level and $\mathrm{SO} 2$ emissions are expected to increase more than four fold between 1990 and 2020. Therefore, in the coming years, large portions of Northern and Western India specifically Delhi, Agra, Chembur, Thane, Trombay, Belapur, Pune, Nagpur, Korba, Singrauli, Kodaikanal etc. are expected to be severely affected with acidic rainfall (Mohan and Kumar, 1998).

Acid rain may lead to leaching of essential cations such as $\mathrm{Ca}+2$ and $\mathrm{Mg}+2$

(Byres and Volk, 1981). An increase in concentration of sulphate $\left(\mathrm{SO}_{4}^{-}\right)$, calcium $(\mathrm{Ca}+2)$ and magnesium $(\mathrm{Mg}+2)$ in soil leachate was recorded in plants of sugar maple at the acid rain of $\mathrm{pH} 3.5$ (Hutchinson et al., 1999). Strayer and Alexander (1981) reported that $\mathrm{CO} 2$ production from glucose was significantly reduced after the soil has been exposed to simulated acid rain ( $\mathrm{pH} 3.2)$. Glucose mineralization in the test soils $(\mathrm{pH}$ values of 4.4-7.1) was inhibited acid rain at pH 3.2 but not at 4.1 .

Pea plants showed significant reduction in photosynthesis rates $(\mathrm{PN})$ in response to ambient air pollution ( $\mathrm{SO} 2, \mathrm{NO} 2$ and $\mathrm{O} 3$ ) at various sites in peri- urban areas of Varanasi. There was found significant difference in photosynthesis rate among sites (Rajput and Agrawal, 2004). Gaseous pollutants have been shown to inhibit photosynthesis rate depending upon exposure dose and species involved (Darall, 1989).

Sheridan and Rosenstreter (1973) reported that simulated acid rain destroyed chlorophyll and depressed photosynthesis in moss Tortularuralis. The acid treatment also reduced chlorophyll b concentrations in Pine, and to a less significant extent, in giant sequoia also (Westman and Temple, 1989).

Kumar (1997) observed that accumulation of different biochemical components in leaves of Zea mays cultivars got affected in acid rain treated, $60 \mathrm{~d}$ and $75 \mathrm{~d}$ old plants. Chlorophyll a, b and total chlorophyll were found to be increased at $\mathrm{pH} 4.5$ and 3.5 acid rain and decreased at $\mathrm{pH} 2.0$ acid rain. 
Chlorophyll a was more sensitive to acid rain as compared to chlorophyll $b$ since most pronounced effects were observed in chlorophyll a. Maximum reduction in chlorophyll a as well as chlorophyll b was noticed in cultivar Sweta and minimum reduction of chlorophyll a was noticed in cultivar Ganga-5, and of chlorophyll $b$ in cultivar Ganga-2 at the $2.5 \mathrm{pH}$ acid rain. Carotenoid content in leaves showed significant decrease with an increase in acidity of treatments in both $60 \mathrm{~d}$ and $75 \mathrm{~d}$ old plants. Maximum reduction was noticed at pH 2.5 in cv. Kanchan after 60, as well as, $75 \mathrm{~d}$ and minimum effect was at $\mathrm{pH} 4.5$ in cv. African tall at the age of 60 and $75 \mathrm{~d}$. Chlorophyll content was found to be affected due to low $\mathrm{pH}$ levels in Triticumaestivum plant (Raj et al., 2003). Ramakrishnaiah and Somashekhara (2003) also found that chlorophyll content was reduced due to

Table 1: Estimation of some biochemical components in leaves of Lycopersiconlycopersicum treated with different $\mathrm{pH}$ of acid rain at $20 \mathrm{~d}$ and $40 \mathrm{~d}$.

\begin{tabular}{|c|c|c|c|c|c|c|c|c|c|c|c|c|}
\hline & \multicolumn{12}{|c|}{ Plant age } \\
\hline & \multicolumn{6}{|c|}{$20 \mathrm{~d}$} & \multicolumn{6}{|l|}{$40 \mathrm{~d}$} \\
\hline & \multicolumn{4}{|c|}{ pH of acid water solution } & \multicolumn{2}{|l|}{ CD } & \multicolumn{4}{|c|}{ pH of acid water solution } & \multicolumn{2}{|l|}{ CD } \\
\hline Attribute & 5.6 & 4.5 & 3.5 & 2.5 & $5 \%$ & $1 \%$ & 5.6 & 4.5 & 3.5 & 2.5 & $5 \%$ & $1 \%$ \\
\hline \multirow{2}{*}{$\begin{array}{l}\text { Leaf extract } \\
\text { pH }\end{array}$} & 6.456 & 6.266 & $5.706^{* *}$ & $5.032 * *$ & \multirow{2}{*}{0.249} & \multirow{2}{*}{0.292} & 6.363 & $6.076^{* *}$ & $5.433 * *$ & $5.610^{* *}$ & \multirow{2}{*}{0.139} & \multirow{2}{*}{0.164} \\
\hline & \pm 0.055 & \pm 0.068 & \pm 0.180 & \pm 0.133 & & & \pm 0.325 & \pm 0.159 & \pm 0.250 & \pm 0.426 & & \\
\hline RWC & 86.17 & 84.062 & 83.333 & 82.86 & - & - & 85.65 & 84.826 & 83.264 & 82.164 & - & - \\
\hline Chla & 0.05 & 0.863 & 0.739 & $0.779^{* *}$ & \multirow{2}{*}{0.129} & \multirow{2}{*}{0.151} & 1.24 & $0.976^{\text {*** }}$ & $0.872 * *$ & 0.847 ** & \multirow{2}{*}{0.105} & \multirow{2}{*}{0.124} \\
\hline$\left(\mathrm{mg} \mathrm{g}^{-1}\right.$ f.wt.) & \pm 0.035 & \pm 0.068 & \pm 0.032 & \pm 0.041 & & & \pm 0.120 & \pm 0.031 & \pm 0.060 & \pm 0.047 & & \\
\hline Chl $b$ & 0.708 & $0.627^{* *}$ & 0.605 & 0.58 & \multirow{2}{*}{0.638} & \multirow{2}{*}{0.075} & 1.03 & 0.956 & 0.759 ** & 0.645 ** & \multirow{2}{*}{0.109} & \multirow{2}{*}{0.128} \\
\hline (mg g f.wt.) & \pm 0.049 & \pm 0.026 & \pm 0.030 & \pm 0.024 & & & \pm 0.061 & \pm 0.031 & \pm 0.054 & \pm 0.043 & & \\
\hline $\begin{array}{l}\text { Chlorophyll } \\
\text { stability index }\end{array}$ & 100 & 96.136 & 86.284 & 86.928 & - & - & 100 & 85.632 & 71.265 & 65.246 & - & - \\
\hline Carotenoids & 0.741 & 0.81 & 0.641 & $0.614^{*}$ & \multirow{2}{*}{0.123} & \multirow{2}{*}{0.145} & 1.603 & 1.489 & $1.309^{* *}$ & 0.879 ** & \multirow{2}{*}{0.154} & \multirow{2}{*}{0.147} \\
\hline$\left(\mathrm{mg} \mathrm{g}^{-1}\right.$ f.wt.) & \pm 0.029 & \pm 0.037 & \pm 0.018 & \pm 0.017 & & & \pm 0.019 & \pm 0.033 & \pm 0.023 & \pm 0.048 & & \\
\hline Anthocyanin & 0.034 & 0.024 & $0.018^{*}$ & $0.016^{*}$ & \multirow{2}{*}{0.153} & \multirow{2}{*}{0.18} & 0.04 & 0.034 & 0.028 ** & 0.023 ** & \multirow{2}{*}{0.009} & \multirow{2}{*}{0.011} \\
\hline (mg g f.wt.) & \pm 0.002 & \pm 0.001 & \pm 0.001 & \pm 0.002 & & & \pm 0.004 & \pm 0.004 & \pm 0.002 & \pm 0.003 & & \\
\hline Protein & 15.749 & 14.634 & $13.204 * *$ & $12.229^{* * *}$ & \multirow[b]{2}{*}{1.829} & \multirow{2}{*}{2.148} & 19.58 & 19.333 & 18.385 & $15.841^{*}$ & \multirow{2}{*}{3.471} & \multirow{2}{*}{4.076} \\
\hline$\left(\mathrm{mg} \mathrm{g}^{-1}\right.$ f.wt.) & \pm 0.847 & \pm 0.616 & \pm 0.758 & \pm 1.075 & & & \pm 1.999 & \pm 1.894 & \pm 1.671 & \pm 1.674 & & \\
\hline Carbohydrate & 22.685 & $20.598 * *$ & $19.574 * *$ & $18.753 * *$ & 1661 & 1051 & 29.95 & 28.04 & $25.525^{* *}$ & $24.398 * *$ & 2693 & 3151 \\
\hline (mg g $\mathrm{g}^{-1}$ d.wt.) & \pm 1.024 & \pm 1.300 & \pm 1.147 & \pm 1.243 & 1.661 & 1.951 & \pm 2.400 & \pm 1.214 & \pm 1.107 & \pm 0.754 & 2.083 & 3.151 \\
\hline APTI & 8.707 & 8.503 & 8.457 & 8.422 & - & - & 8.699 & 8.656 & 8.553 & 8.435 & - & - \\
\hline
\end{tabular}

pollution. Rajput and Agrawal (2004) in a study aimed to assess the effect of ambient air pollution on physiological as well as yield characteristics of pea plants grown at different sites in periurban areas of Varanasi, found that total chlorophyll content was less at polluted sites in comparison to reference sites. Carotenoid content was found reduced. Rabe and Kreeb (1979) reported the diminution of protein contents and the increased activities of the enzymes glucose6-phosphate dehydrogenase, isocitrate dehydrogenase, alanine aminotransferase and glutamate dehydrogenase as indicators of low pollution levels, which don't produce visible damage on plants. Sarkar et al. (1986) found a close correlation between the distance of plants from the roadside and acceleration in peroxidase and catalase activities. 
Estimation of some Biochemical Parameters in Lycopersiconlycopersicum (L.) cv. Damyanti in Response to Acid Rain

Pratibha Tomar

\section{Observations:}

The assessment studies were conducted on three economically important vegetable crops of the family Solanaceae to assess their sensitivity to different $\mathrm{pH}$ of acid rain viz. 5.6, 4.5, 3.5 and 2.5. The choice of the above concentrations was made to observe the limit of the tolerance of the test plants to simulated acid rain. The plants selected for experiments were:

Lycopersiconlycopersicum (L.) Karsten (= Lycopersiconesculentum Mill.) cv. Damyanti

The seeds were obtained from a local National Seed Corporation (NSC) shop of Meerut. Observations were made on the morphological, reproductive and biochemical makeup of plant species. Seeds of
Lycopersiconlycopersicum were sown in small polythene bags filled with sandy loam soil. Before filling the bags, soil was well pulverised and homogenised with equal amount of farm manure. During the course of experiment, normal agronomic practices were followed and no pesticide or fertilizer was added. Solutions of different $\mathrm{pH}$ values viz. 5.6, 4.5, 3.5, and 2.5 were prepared using a combination of sulphuric acid and nitric acid in the ratio of 7:3 v/v (Lee et al., 1981). The solution of $\mathrm{pH} 5.6$ was taken as control. For the evaluation of response of biochemical machinery of plants to acid rain the following biochemical attributes were studied on the leaves and fruits of two test plant at an interval of 20 days.

Table2: Estimation of some biochemical components in leaves of Lycopersiconlycopersicum treated with different $\mathrm{pH}$ of acid rain at $60 \mathrm{~d}$ and $80 \mathrm{~d}$.

\begin{tabular}{|c|c|c|c|c|c|c|c|c|c|c|c|c|}
\hline & \multicolumn{12}{|c|}{ Plant age } \\
\hline & \multicolumn{6}{|c|}{$60 \mathrm{~d}$} & \multicolumn{6}{|c|}{$80 \mathrm{~d}$} \\
\hline & \multicolumn{4}{|c|}{ pH of acid water solution } & \multicolumn{2}{|l|}{ CD } & \multicolumn{4}{|c|}{ pH of acid water solution } & \multicolumn{2}{|l|}{ CD } \\
\hline Attribute & 5.6 & 4.5 & 3.5 & 2.5 & $5 \%$ & $1 \%$ & 5.6 & 4.5 & 3.5 & 2.5 & $5 \%$ & $1 \%$ \\
\hline \multirow{2}{*}{$\begin{array}{ll}\text { Leaf } & \text { extract } \\
\text { pH } & \\
\end{array}$} & 6.043 & $5.640 * *$ & $5.420 * *$ & $5.153 * *$ & \multirow{2}{*}{0.156} & \multirow{2}{*}{0.183} & 6 & 5.8 & $5.400 * *$ & $5.246^{* *}$ & \multirow{2}{*}{0.24} & \multirow{2}{*}{0.278} \\
\hline & \pm 0.166 & \pm 0.100 & \pm 0.100 & \pm 0.040 & & & \pm 0.100 & \pm 0.100 & \pm 0.100 & \pm 0.050 & & \\
\hline RWC & 86.26 & 82.624 & 80.256 & 80.01 & - & - & 85.555 & 80.45 & 78.442 & 70.24 & - & - \\
\hline Chla & 2.631 & $1.567 * *$ & $1.186^{* *}$ & $1.174 * *$ & \multirow{2}{*}{0.516} & \multirow{2}{*}{0.606} & 3.303 & 3.27 & $1.806^{* *}$ & $1.106^{* *}$ & \multirow{2}{*}{0.28} & \multirow{2}{*}{0.323} \\
\hline (mg g ${ }^{-1}$ f.wt.) & \pm 0.208 & \pm 0.167 & \pm 0.246 & \pm 0.147 & & & \pm 0.185 & \pm 0.081 & \pm 0.166 & \pm 0.150 & & \\
\hline Chlb & 2.022 & $1.251 * *$ & $1.094 * *$ & 1.054 & \multirow{2}{*}{0.633} & \multirow{2}{*}{0.743} & 1.585 & $1.324 * *$ & 1.131 & $1.001 * *$ & \multirow{2}{*}{0.16} & \multirow{2}{*}{0.19} \\
\hline (mg g ${ }^{-1}$ f.wt.) & \pm 0.693 & \pm 0.281 & \pm 0.121 & \pm 0.162 & & & \pm 0.152 & \pm 0.205 & \pm 0.220 & \pm 0.122 & & \\
\hline $\begin{array}{l}\text { Chlorophyll } \\
\text { stability index }\end{array}$ & 100 & 60.605 & 48.69 & 47.638 & - & - & 100 & 97.87 & 59.938 & 43.15 & - & - \\
\hline Carotenoids & 1.615 & $1.424 * *$ & $1.402 * *$ & $1.365 * *$ & \multirow{2}{*}{0.051} & \multirow{2}{*}{0.107} & 1.352 & 1.327 & $1.064 * *$ & $0.898 * *$ & \multirow{2}{*}{0.13} & \multirow{2}{*}{0.155} \\
\hline (mg g ${ }^{-1}$ f.wt.) & \pm 0.015 & \pm 0.033 & \pm 0.002 & \pm 0.047 & & & \pm 0.011 & \pm 0.020 & \pm 0.056 & \pm 0.041 & & \\
\hline Anthocyanin & 0.049 & 0.047 & 0.042 & $0.031 * *$ & \multirow{2}{*}{0.007} & \multirow{2}{*}{0.008} & 0.058 & $0.052 * *$ & $0.045^{* *}$ & $0.038^{* *}$ & & \multirow{2}{*}{0.002} \\
\hline (mgg ${ }^{-1}$ f.wt.) & \pm 0.003 & \pm 0.004 & \pm 0.005 & \pm 0.003 & & & \pm 0.002 & \pm 0.004 & \pm 0.004 & \pm 0.004 & & \\
\hline Protein & 25.35 & 24.13 & $21.424^{* *}$ & 20.040 ** & \multirow{2}{*}{3.187} & \multirow{2}{*}{3.743} & 28.865 & 26.29 & $24.361^{* *}$ & $20.606^{* *}$ & \multirow{2}{*}{2.69} & \multirow{2}{*}{3.159} \\
\hline (mg g ${ }^{-1}$ f.wt.) & \pm 2.207 & \pm 1.631 & \pm 0.625 & \pm 1.581 & & & \pm 1.356 & \pm 1.040 & \pm 1.525 & \pm 1.244 & & \\
\hline Carbohydrate & 41.79 & $38.582 * *$ & $36.232 * *$ & $34.432 * *$ & 2086 & 245 & 48.982 & 46.66 & $44.686^{* *}$ & $42.503 * *$ & 3.06 & 3.588 \\
\hline (mg g ${ }^{-1}$ d.wt.) & 0.757 & \pm 1.112 & \pm 1.380 & \pm 2.028 & & & \pm 2.583 & \pm 2.433 & \pm 2.613 & \pm 2.218 & & \\
\hline APTI & 9.032 & 8.604 & 8.345 & 8.327 & - & - & 9.259 & 8.712 & 8.439 & 7.618 & - & - \\
\hline
\end{tabular}




\section{Result and Discussion:}

Exposure to simulated acid rain affected biochemical components of leaves in treated plants and caused them to subside to a great extent. Low $\mathrm{pH}$ of simulated acid rain proved more toxic to the green pigments of treated plants as compared to the higher pH. Chlorophyll $a$, chlorophyll $b$ and total chlorophyll was found to be reduced under the stress of acid rain. The simulated acid rain of $\mathrm{pH} 2.5$ was found most effective. Chlorophyll a level in the leaves of Lycopersiconlycopersicum showed maximum percent reduction value of 66.66 at $\mathrm{pH}$ 2.5. Chlorophyll $b$ content decreased profoundly and maximum percent decline in $L$ was 36.84 at $2.5 \mathrm{pH}$. Similar effects were observed for total chlorophyll content in the treated plants. The values of total chlorophyll at $\mathrm{pH} 5.6$ and 2.5 of simulated acid rain were 4.788 and 2.004 respectively.

Influence of simulated acid rain on carotenoids, the accessory pigments, meant for photoprotection at different ages of plants was also observed. The values attained ( $\mathrm{mg}$ $\mathrm{g}^{-1}$ f.wt.) in leaves of Lycopersiconlycopersicum (80 d old) were $1.327,1.064$ and 0.898 at $\mathrm{pH} 4.5,3.5$ and 2.5 , respectively.

Simulated acid rain also induced considerable alteration in anthocyanin content of experimental crops. The amount of anthocyanin exhibited linear relation with the $\mathrm{pH}$ of simulated acid rain and the values observed were $0.092,0.045$ and 0.038 at
UGC Approved Journal No. 63640 $\mathrm{pH} 4.5,3.5$ and 2.5 , respectively.

Proline content was also measured in test crops, data analysis shows that simulated acid rain treatment also altered the proline content in the experimental crops. The proline content in $80 \mathrm{~d}$ old leaves of the test plants was $0.483,0.528$ and 0.608 at $\mathrm{pH}$ $4.5,3.5$ and 2.5 , respectively.

The relative water content (RWC) also exhibited reduction in accordance with acidity of simulated acid rain. Percent decline in RWC in the plants was recorded and the values attained were 5.97, 8.31 and 17.89 at $\mathrm{pH}$ values $4.5,3.5$ and 2.5 , respectively. Carbohydrate and protein contents were also assessed in the plants under observation. The carbohydrate content showed significant reduction with an increase in the acidity of simulated acid rain. Most significant reduction in carbohydrate content was obtained at $\mathrm{pH} 2.5$. The values of percent reduction in carbohydrate in leaves of Lycopersiconlycopersicum was 13.19 percent at $\mathrm{pH} 2.5$. Simulated acid rain exerted negative impact on Air Pollution Tolerance Index (APTI) of presently studied crops. The APTI of any plant indicates the tolerance capacity of any plant under stress. The result shows that plants exposed to $\mathrm{pH}$ of 5.6 have highest value of APTI, while those treated with APTI at 5.6 and $2.5 \mathrm{pH}$ of simulated acid rain are 9.259 and 7.618 in Lycopersiconlycopersicum (80 d old) respectively. 
Estimation of some Biochemical Parameters in Lycopersiconlycopersicum (L.) cv. Damyanti in

Response to Acid Rain

Pratibha Tomar

\section{References:}

Aber JD, CL Goodale, SV Ollinger, ML Smith, AH Magill, ME Martin, RA Hallett, JL Stoddard, 2003. Is nitrogen deposition altering the nitrogen status of northeastern forests? Bioscience 53: 375-389.

Asano Y and T Uchida 2005. Quantifying the role of forest soil and bedrock in acid neutralization of surface water in steep hillslopes. Environ Pollut 133: 467-480.

Bhatti N., 1992. Acid rain in Asia. Environ Manag16: 541-562.

Bowman AF, DPV Vuuren, RGDerwent., M Posch ,2002. A global analysis of acidification and eutrophication of terrestrial ecosystems. Water, Air, Soil Pollut141: 349-382.

Byers GE and BG Volk 1981. The effects of acid rain on the movement of ions in a quartzipsamment soil under natural conditions in Florida. AgronAbstrAmerSocAgron. Madison WIP 22.

Darall NM 1989. The effect of air pollutants on physiological processes in plants. Plant Cell Environ12: 1 - 30.

Fang YT, P Gunderson, RD Vogt, K Koba, FS Chen, XY Chen and M Yho 2011. Atmospheric deposition and leaching of Nitrogen in Chinese forest ecosystem. J For Res16: 341-350 Galloway JN, GE Linkens and ES Edgerton 1976. Acid rain precipitation in North Western United States. $p H$ and Acidity 194: 722 - 724.

Hutchinson TC, SA Watmough, EPS Sager and JD Karagatzides1999. The impact of simulated acid rain and fertilizer application on a mature sugar maple (Acer saccharum) marsh forest in Central Ontario, Canada. Water Air Soil Pollut109 (1 - 4) : 17 - 29.

Kang Y, M Liu, Y Song, X Huang, H Yao, X Cai, H Zhang, L Kang, X Liu, X Yan, H He, M Shao and T Zhu 2016. High-resolution ammonia emissions inventories in China from 19802012. AtmosChemPhysio16: 2043-2058.

Kumar V 1997. Effect of simulated acid rain on Zea mays L. A Ph.D. Thesis, Chaudhary Charan Singh University, Meerut.

Larssen T and GR Carmichael 2000. Acid rain and acidification in China: the importance of base cation deposition. Environ Pollut110: 89-102.

Larssen T, L Duan and J Mulder 2011. Deposition and leaching of sulfur, nitrogen and calcium in four forested catchments in China: implications for acidification. Environ SciTechnol45: 1192-1198.

Lee JJ, GE Neely, SC Perrigan and LS Grothaus 1981. Effect of simulated acid rain on yield growth and foliar injury of several crops. Environ Exp Bot21: 171 - 185.

Lei Y, Q Zhang, K B He and D G Streets 2011. Primary anthropogenic aerosol emission trends for China, 1990-2005. AtmosChemPhysiol11: 931-954. 
Likens, G.E., and F.H. Bormann. 1995. Biogeochemistry of a forested ecosystem. SpringerVerlag. N.Y. 162 pp.second edition 2001

Mohan M and Kumar 1998. Review of acid rain potential in India: Future threats and remedial measures. CurrSci75 (6): 579 - 593.

Negi SS 1983. Acid rains. In Environmental Conservation (eds) B Singh and MP Singh, Dehradun. pp. 45.

Rabe R and KH Kreeb 1979. Enzyme activities and chlorophyll and protein content in plants as indications of air pollution. Environ Pollut 19.

Raj Sonia, S Devpura, MD Soloman, TI Khan 2003. Simulated acid rain exposure on Triticumaestivumvar Raj 3077 and its impact on growth and physiological parameters. Dimensions Pollut 2: 87 - 94.

Rajput M and M Agrawal 2004. Physiological and yield responses of pea plants to ambient air pollution. Indian J Plant Physiol9 (1): 9 - 14.

Ramakrishnaiah H and RK Somashekhara 2003. Higher plants as biomonitors of automobile pollution. Eco Environ Conserv 9 (3): 337 - 343.

Sarkar RK, A Banerjee and S Mukherji 1986. Acute ratio of peroxidase and catalase activities in leaves of wild dicotyledonous plants as an indication of automobile exhaust pollution. Environ Pollut42: 289 - 295.

Sheridan RP and R Rosenstreter 1973. The effect of $\mathrm{H}+$ on concentration in simulated rain on the mass Tortularuralis. Bryologist76: 168 - 173.

Strayer RF and M Alexander 1981. Effect of simulated acid rain or glucose mineralization and some physicochemical properties of forest soils. J Environ Qual10: 460 - 465.

Vet R, RS Artz, S Carou, M Shaw, CU Ro, W Aas, A Baker, VC Bowersox, F Dentener, LC Galy, A Hou, JJ Piennar, R Gillett, MC Forti, S Gromov, H Hara, T Khodzherm, NM Mahowald, S Nickovic, PSP Rao and NW Reid 2014. A global assessment of precipitation chemistry and deposition of sulfur, nitrogen, sea salt, base cations, organic acids, acidity and $\mathrm{pH}$ and phosphorus. Atmos Environ93: 3-100.

Westman WE and PJ Temple 1989. Acid mist and ozone effect on the leaf chemistry of two western conifer species. Environ Pollut57: 9 - 26.

Zhu XY, L Duan, GG Tang, JM Hao and GX Dong 2004. Estimations of atmospheric emissions of base cations in China. J Tsinghua UnivSciTechnol44: 1176-1179 (in Chinese). 